Keywords: family history; oesophageal squamous cell carcinoma; environmental exposure; xenobiotic gene polymorphisms; interaction and Kashmir

\title{
Family history of cancer and the risk of squamous cell carcinoma of oesophagus: a case-control study in Kashmir, India
}

\author{
G A Bhat ${ }^{1}$, I A Shah ${ }^{1}$, R Rafiq ${ }^{1}$, S Nabi ${ }^{1}$, B lqbal ${ }^{1}, \mathrm{M} \mathrm{M} \mathrm{Lone}{ }^{2}, \mathrm{~F}$ Islami ${ }^{3,4}$, P Boffetta ${ }^{5}$ and N A Dar ${ }^{\star * 1}$
}

${ }^{1}$ Department of Biochemistry, University of Kashmir, Srinagar 190006, India; ${ }^{2}$ Departments of Radiation Oncology, SK Institute of Medical Sciences, Soura Srinagar, 190011 India; ${ }^{3}$ Surveillance and Health Services Research, American Cancer Society, Atlanta, GA, USA; ${ }^{4}$ Digestive Oncology Research Center, Digestive Disease Research Institute, Tehran University of Medical Sciences, Tehran, 14117 Iran and ${ }^{5}$ Tisch Cancer Institute and Institute for Transitional Epidemiology, Mount Sinai School of Medicine, New York, NY, USA

Background: Only a few studies have examined the association between family history of cancer (FHC) and the risk of oesophageal squamous cell carcinoma (ESCC) in high incidence areas of ESCC. We conducted a case-control study to evaluate the relationship between FHC and ESCC risk in Kashmir, India, with analysis of detailed epidemiological data and information on multiple gene polymorphisms.

Methods: We collected detailed information on FHC and a number of socio-demographic and lifestyle factors, and also obtained blood samples for genetic analysis from 703 histopathologically confirmed ESCC cases and 1664 individually matched controls. Conditional logistic regression models were used to calculate odds ratios (ORs) and 95\% confidence intervals (95\% Cls).

Results: Participants who had FHC showed a strong association with ESCC risk, and the risk was stronger when first-degree relatives (FDRs) had $\mathrm{FHC}(\mathrm{OR}=6.8 ; 95 \% \mathrm{Cl}=4.6-9.9)$. Having a sibling with a cancer showed the strongest association $(\mathrm{OR}=10.8$; $95 \% \mathrm{Cl}=6.0-19.3)$, but having a child with a cancer was not associated with ESCC risk. A history of any cancer in the spouse was also associated with $E S C C$ risk $(\mathrm{OR}=4.1 ; 95 \% \mathrm{Cl}=1.6-10.2)$. Those with two or more relatives with $\mathrm{FHC}$ were at a higher risk of ESCC. After restricting FHC to familial ESCC only, the above associations were strengthened, except when spouses were affected with ESCC $(\mathrm{OR}=2.5 ; 95 \% \mathrm{Cl}=0.7-8.9)$. When we examined the associations between several single-nucleotide polymorphisms and ESCC in those with and without FHC, the associations of variant genotypes in cytochrome P450 (CYP) 2C19 and CYP2D6 and the wild genotype of CYP2E1 with ESCC were much stronger in those with FHC. The FHC had an additive interaction with several risk factors of ESCC in this population.

Conclusion: Our results showed that FHC was strongly associated with ESCC risk in Kashmir. It seems both genetic factors and shared environment are involved in this association.

Currently, oesophageal cancer is the eighth most common malignancy and its poor prognosis makes it the sixth most common cause of deaths from cancer globally (Jemal et al, 2011; Levine and Rubesin, 2005). The predominant histological type of oesophageal cancer is the oesophageal squamous cell carcinoma (ESCC), for which $90 \%$ of cases are from Asian regions (Gholipour et al, 2008; Jemal et al, 2011) like northeastern Iran (Islami et al, 2009) and northern China (Tran et al, 2005). The other high-risk regions of the world include Transkei region in South Africa (Pink et al, 2011), Calvados region in France (Desoubeaux et al, 1999), northeast Italy and Uruguay (Franceschi et al, 1995; De Stefani et al, 2003). The ESCC incidence not only differs between high- 
and low-risk areas (where difference might go up to 200-fold (Lukanich, 2003), but it also shows a huge variation among its high-risk regions. The geographical variation in ESCC incidence is attributed to the presence or absence of different environmental or lifestyle risk factors of ESCC in different populations.

Under similar exposures, the ESCC risk is not same across different populations, ethnic groups or even in men and women (Louwman et al, 2010; Thrift et al, 2012; Zhong et al, 2013). This inter-individual difference in ESCC risk under similar exposures is partially attributed to genetic markers harboured by an individual that modulate the effect of environmental and other exposures (Wang et al, 2004; Guengerich, 2008), which are most likely inherited into descendants. The frequent occurrence of cancers in a family suggests a heritable genetic predisposition for ESCC. In other words, family history of cancer (FHC) can be a proxy of genetic vulnerability among the family members (especially in the first-degree relatives, FDRs), who usually have common genetic background. The outcome of prospective twin cohort (Lichtenstein et al, 2000), segregation and migration studies (Zhang et al, 2000) as well as findings like onset of ESCC at a younger age (Jia et $a l, 2014$ ) and the familial clustering of ESCC (Chang-Claude et al, 1997) strongly support the inheritance of genetic susceptibility of ESCC. In addition, FHC can also reflect sharing of same environmental exposures by members of a family (Kato et al, 1990).

Unlike low-risk regions of the ESCC (Dhillon et al, 2001), the FHC has been positively associated with the ESCC risk in high incidence areas (Gao et al, 2009; Turati et al, 2013). Till date, only one study has reported some genetic loci/markers, linked with hereditary of ESCC risk (Ko et al, 2014). Identification of more loci/genetic markers will help to understand the genetic component of ESCC risk associated with FHC further. Xenobiotic metabolising enzymes (XMEs) are involved in several defense mechanisms by handling the toxic environmental exposures (Xing et al, 2003; Yang et al, 2005a, b). The various polymorphisms in XME genes result in their activity differences, hence individuals who harbour different variants of such genes can unlikely have a similar risk of a cancer. Hence, XME markers can be important in studying the genetic bases of FHC. The analysis of the ESCC risk due to XME markers in combination with FHC is not explored yet. However, a study (Wu et al, 2011b) has analysed the modifying effect of FHC on relationship of oesophageal cancer with its various environmental risk factors.

In Kashmir, ESCC is the most common cancer (Rasool et al, 2012) both in males and females with age-standardised incidence rates of 42.6 in men and 27.5 in women per $10^{5}$ person-years (Khuroo et al, 1992). A number of risk factors have been associated with the ESCC susceptibility in Kashmir, including tobacco use (Dar et al, 2012), low socioeconomic status (Dar et al, 2013b), daily and close animal contact (Dar et al, 2014b), poor oral hygiene (Dar et al, 2013a), salt tea intake (Dar et al, 2014a) and consumption of $\mathrm{N}$-nitrosamine containing food items (Siddiqi et al, 1988) as well as certain genetic markers (Bhat et al, 2014; Makhdoomi et al, 2015). Neither relative risks of such factors nor their prevalence in Kashmir is of a reasonable magnitude to explain the high incidence of ESCC in Kashmir. Nevertheless, these finding, suggest the exposure of the Kashmiri population to a range of toxic substances, which are handled by the XMEs. In addition, Kashmir is a non-migrant pure ethnic Muslim-dominated population (Ayub et al, 2011) and consanguineous marriages are common (Fareed and Afzal, 2014), hence the frequent admixture of genetic markers is unlikely to happen. Therefore, studying the possible familial factors (genetic as well as environmental) might give deeper insight into the ESCC aetiology. Hence, we carried out a case-control study to investigate in detail the relationship of FHC with ESCC risk and modifying effects of $\mathrm{FHC}$ on various risk factors of ESCC.

\section{MATERIALS AND METHODS}

Case-control selection and data collection. Details of the subject selection and recruitment are provided elsewhere (Dar et al, 2012). Briefly, all ESCC cases were recruited at the Regional Cancer Centre and Department of Radiation Oncology of Sher-i-Kashmir Institute of Medical Sciences (SKIMS), Srinagar, from September 2008 to January 2012. All cancer patients in Kashmir are referred to SKIMS, the only available tertiary care hospital in Kashmir. Cases with histopathologically confirmed ESCC, who were above the age of 18 years, had not received any treatment and did not have any personal history of cancer, were invited to participate in this study. For each case subject, we attempted to recruit at least one hospital-based control, individually matched to the case for sex, age ( \pm 5 years) and place of residence. The controls were recruited from in-patient wards of SKIMS, the Government Medical College Hospital, Srinagar, and district hospitals to ensure the controls are residence matched to their respective cases. The refusal rate for cases and controls was only $4 \%$ (30 refusals, out of 733 invited) and 2\% (33 refusals out of 1697 invited), respectively. The majority of those who refused were too ill to participate in the study. The maximum interval between recruitment of cases and their controls was 6 months. We included a large number of diseases that allowed us to catch a larger section of the population and increased the representation of the population. However, only those patients were enrolled as controls when the disease for which they had been admitted, did not have a strong association with tobacco or alcohol consumption (the two main factors associated with ESCC risk) and did not affect the dietary habits of the patients (like diabetes). The major reasons for hospitalisation of the enrolled controls are provided elsewhere (Dar et al, 2014b, 2015). This study was reviewed and approved by the Institutional Ethics Committee of SKIMS.

After obtaining informed consent from all the participants, questionnaire developed for the population was administered in face-to-face interviews in the local language. Cases and controls were interviewed during their hospital stay and information on various socio-demographic characteristics, lifestyle factors and dietary information was obtained, the details of which are provided elsewhere (Dar et al, 2012).

Detailed information on FHC was obtained from all the participants. If participants had FHC, further information on type of relation was asked to know whether their FDRs (including father, mother, siblings and offspring), second-degree relatives (including cousins, uncles, aunts, stepsiblings) or spouses had been diagnosed with any type of cancer. Further information on the type(s) and site(s) of cancer as well as age at which malignancy was diagnosed in relatives was also obtained. The information on FHC was checked by cross interviewing the relative of the participants who attended or visited them in the hospital, wherever possible.

In addition, blood sample was collected from each subject for DNA extraction. DNA was analysed for genotyping in XME genes, cytochrome p450 (CYP), glutathione -S-transferases (GSTs), alcohol dehydrogenases $2(A D H 2)$ and aldehyde dehydrogenases 2 (ALDH2). DNA extraction and genotypes for CYP and GSTs and their association with ESCC in Kashmir is provided elsewhere (Bhat et al, 2014; Makhdoomi et al, 2015), however, details of genotype analysis for $A L D H$ and $A D H$ genes are provided in the Supplementary Text 1.

Statistical analysis. Conditional logistic regression models were used to calculate unadjusted and adjusted odds ratios (ORs) and 95\% confidence intervals (95\% CIs) as well as to assess interactions. Confounders against which adjustment was made include age, ethnicity, religion, animal contact, oral hygiene, hookah smoking, nass chewing, alcohol consumption, daily fresh fruit and vegetable 
intake and salt tea drinking. The confounders are known risk factor of ESCC particularly in the study population (Dar et al, 2012, $2013 a, b, 2014 b, 2015)$. Age was included in the multivariate models, because the matching for age was not perfect ( \pm 5 years). Adjustments were done for cumulative wealth scores, place of residence and education level as indicators of socioeconomic status. To assess the socioeconomic status, we built a composite score for wealth, based on appliances ownership and other variables by using multiple correspondence analysis (Islami et al, 2009). Information on multiple correspondence analysis-based wealth score calculation is provided elsewhere (Dar et al, 2013b). Fruit and vegetable intake data ( $g$ per day) were transformed to logarithmic values following the addition of 0.1 to original values.

Parents, siblings and children were included as FDRs, whereas relatives like cousins, uncle, aunt, stepsiblings were categorised as second-degree relatives or other relatives and participants with FHC in spouse were put in a separate category. Cancers (including head and neck, breast, liver, pancreas, urogenital, skin and leukaemias and lymphomas), which were modest in number were grouped as 'other cancers'. The participants who had FHC or history of cancer in FDRs (FHC-FDRs) were grouped together, and those with family history of ESCC (FH-ESCC) were put in a separate group for further analysis. FHC was considered positive when at least one FDRs had been diagnosed with any type of cancer. In case of FH-ESCC, FHC was regarded positive when at least one FDR or two other relatives in a family had ESCC.

The participants were also grouped based on the frequency and type of genotype allele they carried. With respect to CYP genes, individuals had either homozygous wild or variant genotype (variant genotype has at least one or both mutant alleles). The wild genotypes of CYP2A6a, CYP2A6b, CYP2A6c, CYP2A13, CYP2C19, CYP2D6 and CYP2E1 are ${ }^{\star} 1 A /{ }^{*} 1 A,{ }^{*} 1 /{ }^{\star} 1,{ }^{*} 1 A /{ }^{*} 1 A,{ }^{*} C /{ }^{*} C,{ }^{*} 1 /{ }^{\star} 1$, $G / G$ and $c 1 / c 1$, whereas the variant genotypes are ${ }^{*} 1 A /{ }^{*} 6+{ }^{*} 6 /{ }^{*} 6$,

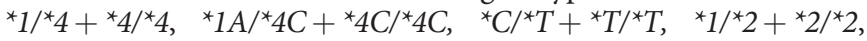
$G / A+{ }^{\star} A /{ }^{\star} A$ and $c 1 / c 2+c 2 / c 2$, respectively. In case of GSTs, the wild and null genotype conditions were represented as $G S T M^{+}$, $\mathrm{GSTT1}^{+}$and GSTTM ${ }^{-}, \mathrm{GSTT1}^{-}$, respectively. However, in case of $A L D H 2$ and $A D H 2$, the wild genotypes in both the genes were represented as $2^{\star} 1 / 2^{\star} 1$, whereas mutant homozygous had $2^{\star} 2$ / $2^{\star} 2+2^{\star} 2 / 2^{\star} 2$ combination. All statistical analysis was done using STATA software, version 12 (STATA Corp., College Station, TX, USA). Two-sided $P$ values $<0.05$ were considered as statistically significant.

\section{RESULTS}

The general characteristics of the participants are presented in Table 1. Table 2 shows the distribution of FHC among participant relatives and its association with ESCC risk. A strong increase in ESCC risk was observed in subjects who had FHC $(\mathrm{OR}=5.8 ; 95 \%$ $\mathrm{CI}=4.1-8.3)$. The risk showed a slight increase when analysis was limited to participants who had FHC-FDRs (OR $=6.8 ; 95 \%$ $\mathrm{CI}=4.6-9.9)$. On analysing the sex wise data, both sexes showed similar risk as seen in above subgroups as well as among themselves. On stratifying the subjects on the basis of the relation type, the strongest risk of ESCC was found when siblings had FHC $(\mathrm{OR}=10.8 ; 95 \% \mathrm{CI}=6.0-19.3)$. Association between $\mathrm{FHC}$ and ESCC risk was also noticed in participants who had FHC among their spouses $(\mathrm{OR}=4.1 ; 95 \% \mathrm{CI}=1.6-10.2)$. The association was not significant when the analysis was done in participants whose children were affected. Increased risk of ESCC was found when several relatives were affected with cancer. The enhanced risk of ESCC was also observed across various groups based on age at diagnosis of cancer in family members.

Strong ESCC risk was observed $(\mathrm{OR}=11.8 ; 95 \% \mathrm{CI}=6.8-20.3)$ when analysis was limited to subjects who had FH-ESCC (Table 3).
The risk turned out stronger, when participants were grouped as FHC-FDRs together $(\mathrm{OR}=16.1 ; 95 \% \mathrm{CI}=8.5-30.0)$, or separately as parents $(\mathrm{OR}=11.4 ; 95 \% \mathrm{CI}=5.0-24.9)$ or siblings $(\mathrm{OR}=28.1$; $95 \% \mathrm{CI}=9.1-85.8$ ). Similarly, very high risk of ESCC was found when participants with FH-ESCC were grouped sex wise. The association was not significant when participant's spouse had FHESCC $(\mathrm{OR}=2.5 ; 95 \% \mathrm{CI}=0.7-8.6)$. The association of ESCC with FH-ESCC was higher when more than one relatives were affected with ESCC. When FHC was further stratified on the basis of organ affected, a substantial increase in ESCC risk was observed only in case of same site FHC (Supplementary Table 1).

The ESCC risk could be estimated only in a few genotypes when the analysis was limited to subjects who had FHC (Table 4). The ESCC risk was very strong in subjects who carried variant genotypes of CYP2C19 $\left({ }^{\star} 1 / 2+{ }^{*} 2 /{ }^{*} 2\right)(\mathrm{OR}=15.5$; $95 \% \mathrm{CI}=7.4-$ 32.3) and CYP2D6 $\left({ }^{*} G / A+{ }^{*} A /{ }^{*} A\right)(\mathrm{OR}=9.7 ; 95 \% \mathrm{CI}=3.6-25.9)$ or wild genotype of $C Y P 2 E 1(c 1 / c 1)(\mathrm{OR}=9.7 ; 95 \% \mathrm{CI}=2.5-37.5)$.

The analysis of the association of major risk factors with ESCC in the presence of FHC is presented in Supplementary Table 2. When FHC was reported, the association of ESCC risk with the known risk factors was appreciably increased. On assessing the interaction between the various environmental exposures and different genotypes of participants with FHC, significant interaction persisted only in adobe house dwellers $\left(P_{\text {interaction }}<0.001\right.$; Supplementary Table 3).

\section{DISCUSSION}

Our analysis showed substantial elevation of ESCC risk with positive FHC and risk was appreciably increased when blood relations had cancer or subjects had same organ cancer history in their families. A strong risk was also found when more than one relative had positive FHC. No risk was found when children of participants suffered from cancer and in case of spouse affected group, the association of ESCC risk did not persist when the analysis was limited to FH-ESCC. ESCC risk did not change when subjects with FHC were classified sex wise. A modifying effect of FHC was observed on ESCC risk in the presence of some important exogenous risk determinants and vulnerable genotypes.

The positive association between FHC and ESCC risk in the current study is consistent with previous studies (Garavello et al, 2005; Akbari et al, 2006; Gao et al, 2009; Turati et al, 2013) from high ESCC risk regions. As compared with these studies from high-risk ESCC, (Garavello et al, 2005; Tran et al, 2005; Akbari et al, 2006; Gao et al, 2009; Wu et al, 2011b), our study showed overall stronger association between ESCC risk and FHC. However, a few epidemiological studies from low-risk regions have reported insignificant associations of FHC-FDRs and oesophageal cancer risk (Lagergren et al, 2000; Dhillon et al, 2001). This inconsistency in different areas might be due to variation in the frequency of oesophageal susceptibility alleles or differences in major attributable exogenous factors and or a combination of both (Akbari et al, 2006). FHC can be a stand-in of shared environmental factors or genetic susceptibility and in the following discussion we have tried to explain the possible contribution of both familial factors in determining the ESCC risk in the context of our results.

The association of FHC with risk of ESCC in participants with affected relatives even at younger age cannot explain the association of FHC and cancer occurrence exclusively based on shared exposure, rather it suggests a role of genetic predisposition as well. Findings from high-risk areas (Hiyama et al, 2007; $\mathrm{Wu}$ et al, 2011b) support the role of genetics in ESCC development. In addition, the consistent molecular profiles within some chromosomal regions from high-risk regions could also support the positive associations of some genes with ESCC risk (Ko 
Table 1. Characteristics of ESCC patients and matched controls from Kashmir, 2008-2012

\begin{tabular}{|c|c|c|c|}
\hline Characteristics & Cases (\%) & Controls (\%) & $P$-value \\
\hline Age, mean (s.d.), years & $61.6( \pm 11.1)$ & $59.8( \pm 11.1)$ & 0.480 \\
\hline Sex & & & 0.78 \\
\hline $\begin{array}{l}\text { Men } \\
\text { Women }\end{array}$ & $\begin{array}{l}393(55.9) \\
310(44.1)\end{array}$ & $\begin{array}{l}920(55.3) \\
744(44.7)\end{array}$ & \\
\hline $\begin{array}{l}\text { Fresh fruit and vegetable, } \\
\text { median g per day (IQR) } \\
\text { intake }\end{array}$ & $1.3(0.8-2.0)$ & $6.1(2.1-72.1)$ & $<0.001$ \\
\hline Place of residence & & & $<0.001$ \\
\hline $\begin{array}{l}\text { Urban } \\
\text { Rural }\end{array}$ & $\begin{array}{c}29(4.1) \\
674(95.9)\end{array}$ & $\begin{array}{c}146(8.8) \\
1518(91.2)\end{array}$ & \\
\hline House type & & & $<0.001$ \\
\hline $\begin{array}{l}\text { Concrete } \\
\text { Adobe }\end{array}$ & $\begin{array}{l}271(38.6) \\
432(61.4)\end{array}$ & $\begin{array}{c}1251(75.2) \\
413(24.8)\end{array}$ & \\
\hline Cooking fuel & & & $<0.001$ \\
\hline $\begin{array}{l}\text { Other } \\
\text { Biomass }\end{array}$ & $\begin{array}{c}16(2.3) \\
685(97.7)\end{array}$ & $\begin{array}{c}298(18.0) \\
1358(82.0)\end{array}$ & \\
\hline Education & & & $<0.001$ \\
\hline $\begin{array}{l}\text { No schooling } \\
\text { Primary ( }<5 \text { th) } \\
\text { Middle (5-8th) } \\
\text { High school (9th-12th) } \\
\text { Graduate and higher }\end{array}$ & $\begin{array}{l}626(89.0) \\
33(4.7) \\
24(3.4) \\
16(2.3) \\
04(0.6)\end{array}$ & $\begin{array}{l}1074(64.5) \\
203(12.2) \\
123(7.4) \\
149(8.9) \\
115(7.0)\end{array}$ & \\
\hline Wealth score & & & $<0.001$ \\
\hline $\begin{array}{l}\text { Cat } 1^{\mathbf{b}} \\
\text { Cat } 2 \\
\text { Cat } 3\end{array}$ & $\begin{array}{l}397(56.5) \\
112(15.9) \\
194(29.6)\end{array}$ & $\begin{array}{l}337(20.3) \\
328(19.7) \\
999(60.0)\end{array}$ & \\
\hline Animal contact & & & $<0.001$ \\
\hline $\begin{array}{l}\text { No or occasional contact } \\
\text { Daily contact } \\
\text { Daily and close contact }\end{array}$ & $\begin{array}{l}164(23.3) \\
175(24.9) \\
364(51.8)\end{array}$ & $\begin{array}{l}774(46.5) \\
616(37.0) \\
274(16.5)\end{array}$ & \\
\hline Oral hygiene & & & $<0.001$ \\
\hline $\begin{array}{l}\text { Do not brush } \\
\text { Ones/week } \\
\text { Twice or thrice/week } \\
\text { Daily }\end{array}$ & $\begin{array}{l}161(22.9) \\
366(52.1) \\
94(13.4) \\
81(11.6)\end{array}$ & $\begin{array}{c}101(6.2) \\
785(47.9) \\
345(21.1) \\
405(24.8)\end{array}$ & \\
\hline Smoking & & & $<0.001$ \\
\hline $\begin{array}{l}\text { Never } \\
\text { Ever }\end{array}$ & $\begin{array}{l}271(38.6) \\
432(61.4)\end{array}$ & $\begin{array}{l}835(50.2) \\
829(49.8)\end{array}$ & \\
\hline Nass chewing & & & $<0.001$ \\
\hline $\begin{array}{l}\text { Never } \\
\text { Ever }\end{array}$ & $\begin{array}{l}502(71.5) \\
201(28.5)\end{array}$ & $\begin{array}{c}1471(88.4) \\
193(11.6)\end{array}$ & \\
\hline Alcohol consumption & & & $<0.001$ \\
\hline $\begin{array}{l}\text { Never } \\
\text { Ever }\end{array}$ & $\begin{array}{c}695(98.9) \\
08(1.1)\end{array}$ & $\begin{array}{c}1664(100.00) \\
0(0.00)\end{array}$ & \\
\hline Tea type & & & 0.041 \\
\hline $\begin{array}{l}\text { Other } \\
\text { Salt tea }\end{array}$ & $\begin{array}{c}09(1.3) \\
693(98.7) \\
\end{array}$ & $\begin{array}{c}51(3.1) \\
1612(96.9) \\
\end{array}$ & \\
\hline \multicolumn{4}{|c|}{$\begin{array}{l}\text { Abbreviations: ESCC = oesophageal squamous cell carcinoma; IQR=inter-quartile range. } \\
\text { a Although cases and controls were individually matched, the percentages of cases and } \\
\text { controls are not necessarily equal in each sex category, because some cases have one } \\
\text { matched control and others have more controls. Numbers may not add up to the total } \\
\text { numbers due to missing data in some variables. } P \text { values calculated using } \chi^{2} \text { tests for } \\
\text { categorical variables ( } \chi^{2} \text { for trend in variables with more than two categories) and Wilcoxon } \\
\text { Rank Sum tests for continuous variables. } \\
{ }^{b} \text { Cat } 1 \text {, cat } 2 \text { and cat } 3 \text { represent the wealth scores in increasing order. }\end{array}$} \\
\hline
\end{tabular}

et al, 2014). Certain cancer vulnerability increasing alleles can modulate the risk of ESCC, which is attributed to a range of biological phenomenon including elevation of the toxicity of certain compounds. For example, in the current study, subjects harbouring vulnerable genotypes of CYP2C19, CYP2D6 and
CYP2E1 and also having FHC had an increased risk of ESCC. Increased ESCC risk among subjects harbouring a variant genotypes of CYP2C19 and CYP2D6 may be possible due to their reduced metabolic activity towards carcinogens, which are usually formed due to activation of toxic compounds present in tobacco smoke (Yadav et al, 2010). The splice mutation at $1934 G$ to $A$ in case of CYP2D6 results in the loss of enzyme activity towards its substrates as compared with its wild-type allele (Gaikovitch et al, 2003) or formation of a truncated protein by a single base pair mutation at $681 G$ to $A$ in case of $C Y P 2 C 19$ results lower enzyme expression and reduced metabolism of preformed or activated carcinogens (Shi et al, 2012). The reduced metabolic activity owing to such gene variants results in increased production of toxic metabolites that could lead to the formation of different biochemical end products including DNA adducts in substratespecific tissues, hence tissue-specific toxicity. However, CYP2E1 has been involved in the activation of nitrosamines-specific procarcinogens (Yang et al, 1990), which results in the increased production of activated carcinogens and hence a possible reason of an increased ESCC risk of wild genotypes (LeMarchand et al, 1999; Tan et al, 2001).

On ESCC, there are four original genome-wide association studies (GWAS; Abnet et al, 2010; Wang et al, 2010; Wu et al, 2011a; Wu et al, 2012) and their two combinational analysis (Wang et al, 2014; Wu et al, 2014) available till date. The five most common loci reported at least in two GWAS are PLCE1 (rs2274223), ALDH2 (rs671), ADH1B (rs1229984), CY1A1 (rs1048943) and CASP-8 (rs3834129). Out of which three loci $A L D H 2, A D H 1 B$ and $C Y 1 A 1$ fall in XME genes, which we have analysed in this study or elsewhere (Bhat et al, 2014). The other two common GWAS identified loci CASP-8 (rs3834129) and PLCE1 (rs2274223) have either showed no association (with CASP8; Malik et al, 2011) or weak association (PLCE1; Malik et al, 2014) with ESCC risk in Kashmir.

In addition, various interesting findings in our study further substantiate the role of genetic predisposition in the familial aggregation of ESCC. First, those who were not exposed to known risk factors in Kashmir including tobacco smoking and nass chewing still showed association of FHC with ESCC risk (Supplementary Table 2). Second, multiple affected relatives showed a dose-dependent relationship with ESCC and higher risk of ESCC was found when FDRs were affected. Third, the elevated risk of ESCC at a younger age as in previous studies (Garavello et al, 2005; Wen et al, 2006). Fourth, the risk of ESCC was not significantly enhanced in subjects with family history of other environment and lifestyle-induced cancer (for example, lung cancer, which is strongly related to smoking; Supplementary Table 1), supports the high risk due to certain cancer riskincreasing alleles in gene pool of families. Fifth, increased ESCC risk in siblings and parents in the current study, like earlier findings (Shao et al, 1997), could be attributed to high penetrant dominant effects of genetic inheritance (Hemminki et al, 2001). Sixth, disappearance of association of various analysed genotypes with ESCC when FHC was absent. Seventh, strongest risk when there was FH-ESCC, although this equally can support shared ESCC risk-increasing exposures in a family. All such results indicate that FHC can be a manifestation of genetic predisposition.

However, the close relationship between FHC and cancer occurrence can also be due to same-shared exposures within a family. In our study, the high risk of ESCC when spouses were affected supports the potential effect of shared risk habits, as supported by migrant studies that show the cancer patterns of immigrants are largely set after the first 2 decades of their life as immigrants (Hemminki and Li, 2002; Hemminki et al, 2002). Besides environmental factors, viral infections like human papilloma virus, could be one of the possible aetiological factors for cervical, penile carcinomas and ESCC, however, conclusive 
Table 2. The distribution of family history of cancer and its association with ESCC in Kashmir

\begin{tabular}{|c|c|c|c|c|}
\hline Variable & Cases $(\% ; N=703$ ) & Controls $(\% ; N=1664)$ & UAOR $(95 \% \mathrm{Cl})$ & $\operatorname{AOR}(95 \% \mathrm{Cl})^{\mathrm{a}}$ \\
\hline \multicolumn{5}{|l|}{ FHC } \\
\hline $\mathrm{No}^{\mathrm{b}}$ & $462(65.7)$ & $1544(92.8)$ & Referent & Referent \\
\hline$Y_{e s}{ }^{c}$ & $241(34.3)$ & $120(7.2)$ & $6.4(4.9-8.2)$ & $5.8(4.1-8.3)$ \\
\hline FDRs & $187(26.6)$ & $89(5.3)$ & $6.6(4.8-8.8)$ & $6.8(4.6-9.9)$ \\
\hline Other & $54(7.7)$ & $31(1.7)$ & $5.6(3.4-9.0)$ & $4.0(2.1-7.6)$ \\
\hline \multicolumn{5}{|l|}{ Gender } \\
\hline Male & $130(18.5)$ & $63(3.8)$ & $6.22(4.4-8.8)$ & $5.5(3.4-8.9)$ \\
\hline Female & $111(15.8)$ & $57(3.4)$ & $6.51(4.4-9.5)$ & $6.2(3.7-10.3)$ \\
\hline \multicolumn{5}{|c|}{ Affected relatives ${ }^{d}$} \\
\hline Parents & 91 (12.9) & $58(3.5)$ & $4.9(3.4-7.0)$ & $4.1(2.4-6.8)$ \\
\hline Father & $54(8.0)$ & $29(1.8)$ & $6.0(3.7-9.9)$ & $5.4(2.7-11.0)$ \\
\hline Mother & $36(5.3)$ & $23(1.4)$ & $4.4(2.6-7.6)$ & $3.1(1.5-6.7)$ \\
\hline Sibling & 98 (13.9) & $30(1.8)$ & $10.5(6.6-16.6)$ & $10.8(6.0-19.3)$ \\
\hline Brother & $66(9.8)$ & $18(1.1)$ & $11.0(6.1-19.9)$ & $10.9(5.3-22.6)$ \\
\hline Sister & $31(4.6)$ & $11(0.7)$ & $9.8(4.6-21.2)$ & $10.1(3.6-28.1)$ \\
\hline Children & $04(0.6)$ & $07(0.4)$ & $1.8(0.5-6.5)$ & $3.8(0.5-30.2)$ \\
\hline Spouse & $24(3.7)$ & $16(1.0)$ & $5.1(2.6-10.1)$ & $4.1(1.6-10.2)$ \\
\hline Other relatives ${ }^{\mathrm{e}}$ & $25(3.4)$ & $15(0.9)$ & $4.8(2.5-9.5)$ & $2.6(1.0-6.8)$ \\
\hline \multicolumn{5}{|c|}{ Affected relatives } \\
\hline 1 & $187(26.6)$ & $112(6.7)$ & $5.2(3.9-6.8)$ & $4.76(3.3-6.9)$ \\
\hline & $54(7.7)$ & $13(0.8)$ & $13.4(7.0-25.5)$ & $11.86(4.9-28.3)$ \\
\hline$P$ for trend & & & $<0.001$ & $<0.001$ \\
\hline \multicolumn{5}{|c|}{ Age at diagnosis of relative (in years) } \\
\hline $1-40$ & $11(1.6)$ & $13(0.8)$ & $3.2(1.3-7.8)$ & $4.1(1.3-13.4)$ \\
\hline $41-50$ & $42(6.0)$ & $28(1.7)$ & $4.7(2.8-7.9)$ & $4.1(1.9-8.9)$ \\
\hline$>50$ & $188(26.7)$ & $79(4.8)$ & $7.3(5.4-9.8)$ & $6.5(6.3-9.8)$ \\
\hline$P$ for trend & & & $<0.001$ & $<0.001$ \\
\hline \multirow{4}{*}{\multicolumn{5}{|c|}{$\begin{array}{l}\text { Abbreviations: } \mathrm{AOR}=\text { adjusted odds ratio; } \mathrm{Cl}=\text { confidence interval; } \mathrm{FDR}=\text { first-degree relative; } \mathrm{FHC}=\text { family history of cancer; } \mathrm{UAOR}=\text { unadjusted odds ratio. } \\
\text { a Adjusted for age, place of residence, education, ethnicity, tobacco smoking, nass consumption, fruit and vegetables, animal contact, oral hygiene, wealth score, ever alcohol.. } \\
\mathrm{b}_{\text {Subject without family histories of any cancer. }} \\
\mathrm{c}_{\text {Family history of any cancer in first or other degree relatives. }}\end{array}$}} \\
\hline & & & & \\
\hline & & & & \\
\hline & & & & \\
\hline \multicolumn{5}{|c|}{ d Relatives were analysed separately to find out their individual effects. } \\
\hline \multicolumn{5}{|c|}{ 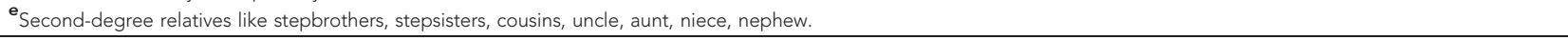 } \\
\hline
\end{tabular}

\section{Table 3. Association of FHC with ESCC exclusively in participants who had positive oesophageal cancer family history}

\begin{tabular}{|c|c|c|c|c|}
\hline Variable & Cases (\%; $N=703)$ & Controls (\%; $N=1664)$ & UAOR $(95 \% \mathrm{Cl})$ & $\operatorname{AOR}(95 \% \mathrm{Cl})^{a}$ \\
\hline No & $462(73.6)$ & $1544(97.8)$ & Referent & Referent \\
\hline Yes $^{\mathbf{b}}$ & $172(27.1)$ & $35(2.2)$ & $15.3(9.9-23.5)$ & $11.8(6.8-20.3)$ \\
\hline FDRs & $140(22.1)$ & $23(1.5)$ & $18.6(11.1-30.9)$ & $16.1(8.5-30.5)$ \\
\hline Other & $32(5.0)$ & $12(0.8)$ & $8.6(4.0-18.4)$ & $4.2(1.6-11.2)$ \\
\hline \multicolumn{5}{|l|}{ Gender } \\
\hline $\begin{array}{l}\text { Male } \\
\text { Female }\end{array}$ & $\begin{array}{l}96(15.1) \\
76(12.0)\end{array}$ & $\begin{array}{l}16(1.0) \\
19(1.1)\end{array}$ & $\begin{array}{r}16.3(8.9-29.8) \\
14.3(7.7-26.4)\end{array}$ & $\begin{array}{l}13.4(6.2-29.4) \\
10.4(4.9-21.9)\end{array}$ \\
\hline \multicolumn{5}{|c|}{ Affected relatives } \\
\hline $\begin{array}{l}\text { Parents } \\
\text { Siblings } \\
\text { Spouse } \\
\text { Other }\end{array}$ & $\begin{array}{l}73(11.5) \\
67(10.6) \\
11(1.7) \\
21(3.3)\end{array}$ & $\begin{array}{l}19(1.2) \\
04(0.3) \\
08(0.5) \\
04(0.3)\end{array}$ & $\begin{aligned} 12.7 & (7.0-22.7) \\
40.0 & (14.3-112.0) \\
5.1 & (1.7-15.0) \\
12.6 & (4.2-37.8)\end{aligned}$ & $\begin{array}{c}11.4(5.0-24.9) \\
28.1(9.1-85.8) \\
2.5(0.7-8.6) \\
8.6(1.7-38.0)\end{array}$ \\
\hline \multicolumn{5}{|c|}{ Number of affected relatives } \\
\hline $\begin{array}{l}1 \\
2 \text { or more } \\
P \text { for trend }\end{array}$ & $\begin{array}{l}74(13.2) \\
23(4.1)\end{array}$ & $\begin{array}{l}85(5.2) \\
08(0.5)\end{array}$ & $\begin{aligned} 2.8 & (1.9-3.9) \\
9.9 & (3.9-24.6) \\
& <0.001\end{aligned}$ & $\begin{array}{l}3.5(2.2-5.6) \\
4.6(1.4-15.0) \\
\quad<0.001\end{array}$ \\
\hline \multicolumn{5}{|c|}{ Age at diagnosis of relative (in years) } \\
\hline $\begin{array}{l}1-40 \\
41-50 \\
>50 \\
P \text { for trend }\end{array}$ & $\begin{array}{c}04(0.6) \\
29(4.3) \\
139(21.9)\end{array}$ & $\begin{array}{l}02(0.1) \\
02(0.1) \\
31(1.9)\end{array}$ & $\begin{array}{c}14.3(2.4-88.4) \\
28.0(6.6-118.8) \\
14.3(8.9-22.4) \\
\quad<0.001\end{array}$ & $\begin{array}{c}10.5(1.2-86.6) \\
17.4(3.2-94.9) \\
11.3(6.3-20.0) \\
<0.001\end{array}$ \\
\hline \multicolumn{5}{|c|}{ 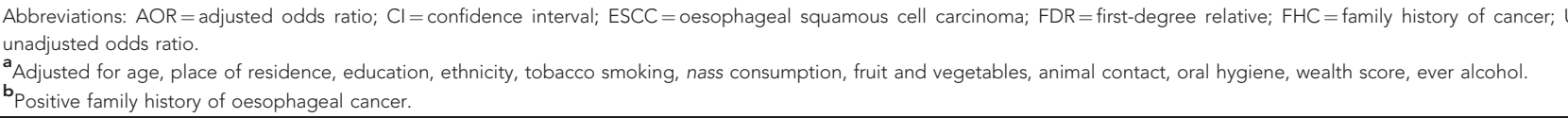 } \\
\hline
\end{tabular}


Table 4. Association of gene polymorphisms with ESCC in subjects with and without FHC

\begin{tabular}{|c|c|c|c|c|c|c|c|c|}
\hline & \multicolumn{4}{|c|}{$\mathrm{FHC}^{-}$} & \multicolumn{4}{|c|}{$\mathrm{FHC}^{+}$} \\
\hline Genotypes\# & $\begin{array}{l}\text { Cases } \\
N(\%)\end{array}$ & $\begin{array}{c}\text { Controls } \\
N(\%)\end{array}$ & $\begin{array}{c}\text { UAOR } \\
(95 \% \mathrm{Cl})\end{array}$ & $\begin{array}{c}\mathrm{AOR}^{a} \\
(95 \% \mathrm{Cl})\end{array}$ & $\begin{array}{l}\text { Cases } \\
N(\%)\end{array}$ & $\begin{array}{c}\text { Controls } \\
N(\%)\end{array}$ & $\begin{array}{c}\text { UAOR } \\
(95 \% \mathrm{Cl})\end{array}$ & $\begin{array}{c}\mathrm{AOR}^{a} \\
(95 \% \mathrm{Cl})\end{array}$ \\
\hline \multicolumn{9}{|l|}{ CYP2A6a } \\
\hline $\begin{array}{l}b * 1 \mathrm{~A} / * 6,{ }^{*} 6 / * 6 \\
{ }^{*} 1 \mathrm{~A} / * 1 \mathrm{~A}\end{array}$ & $\begin{array}{c}55(17.2) \\
264(82.8)\end{array}$ & $\begin{array}{l}111(24.4) \\
343(75.6)\end{array}$ & $\begin{array}{c}\text { Referent } \\
1.5(1.0-2.3)\end{array}$ & $\begin{array}{c}\text { Referent } \\
1.2(0.5-2.7)\end{array}$ & $\begin{array}{c}32(18.5) \\
141(81.5)\end{array}$ & $\begin{array}{l}12(31.6) \\
26(68.4)\end{array}$ & $\begin{array}{c}\text { Referent } \\
2.0(0.2-22.1)\end{array}$ & $\begin{array}{c}\text { Referent } \\
-\end{array}$ \\
\hline \multicolumn{9}{|l|}{ CYP2A6b } \\
\hline $\begin{array}{l}d * 1 / * 4,{ }^{*} 4 / * 4 \\
e \star 1 / * 1\end{array}$ & $\begin{array}{c}69(21.6) \\
250(50.8)\end{array}$ & $\begin{array}{l}120(26.4) \\
334(67.9)\end{array}$ & $\begin{array}{c}\text { Referent } \\
1.3(0.9-1.9)\end{array}$ & $\begin{array}{c}\text { Referent } \\
1.0(0.6-1.6)\end{array}$ & $\begin{array}{c}38(21.9) \\
135(78.9)\end{array}$ & $\begin{array}{l}07(18.4) \\
31(8.6)\end{array}$ & $\begin{array}{c}\text { Referent } \\
-\end{array}$ & $\begin{array}{c}\text { Referent } \\
-\end{array}$ \\
\hline \multicolumn{9}{|l|}{ CYP2A6c } \\
\hline $\begin{array}{l}f_{\star} 1 \mathrm{~A} /{ }^{*} 4 C_{,}{ }^{*} 4 \mathrm{C} /{ }^{*} 4 \mathrm{C} \\
9 * 1 \mathrm{~A} /{ }^{*} 1 \mathrm{~A}\end{array}$ & $\begin{array}{c}68(13.8) \\
251(78.7)\end{array}$ & $\begin{array}{l}162(32.9) \\
292(64.3)\end{array}$ & $\begin{array}{c}\text { Referent } \\
1.9(1.3-2.8)\end{array}$ & $\begin{array}{c}\text { Referent } \\
1.9(0.8-4.1)\end{array}$ & $\begin{array}{c}37(21.4) \\
136(78.6)\end{array}$ & $\begin{array}{l}10(26.3) \\
28(73.7)\end{array}$ & $\begin{array}{c}\text { Referent } \\
4.0(0.4-35.8)\end{array}$ & $\begin{array}{c}\text { Referent } \\
-\end{array}$ \\
\hline \multicolumn{9}{|l|}{ CYP2A13 } \\
\hline 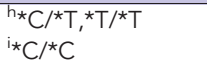 & $\begin{array}{c}65(20.4) \\
254(79.6)\end{array}$ & $\begin{array}{l}134(29.5) \\
320(70.5)\end{array}$ & $\begin{array}{c}\text { Referent } \\
1.4(0.9-2.0)\end{array}$ & $\begin{array}{c}\text { Referent } \\
1.2(0.7-2.1)\end{array}$ & $\begin{array}{c}42(24.3) \\
131(75.7)\end{array}$ & $\begin{array}{l}11(28.9) \\
27(71.1)\end{array}$ & $\begin{array}{c}\text { Referent } \\
4.0(0.4-35.8)\end{array}$ & $\begin{array}{c}\text { Referent } \\
-\end{array}$ \\
\hline \multicolumn{9}{|l|}{ CYP2C19 } \\
\hline $\begin{array}{l}j \star 1 / * 1 \\
k \star 1 / * 2, * 2 / \star 2\end{array}$ & $\begin{array}{l}104(32.6) \\
215(67.4)\end{array}$ & $\begin{array}{l}232(51.1) \\
222(48.9)\end{array}$ & $\begin{array}{c}\text { Referent } \\
2.2(1.6-3.2)\end{array}$ & $\begin{array}{c}\text { Referent } \\
4.1(1.8-9.2)\end{array}$ & $\begin{array}{c}56(32.4) \\
117(23.8)\end{array}$ & $\begin{array}{l}24(63.2) \\
14(36.8)\end{array}$ & $\begin{array}{c}\text { Referent } \\
14.9(8.0-27.6)\end{array}$ & $\begin{array}{c}\text { Referent } \\
15.5(7.4-32.3)\end{array}$ \\
\hline \multicolumn{9}{|l|}{ CYP2D6 } \\
\hline $\begin{array}{l}{ }^{\mathrm{T}} \mathrm{G} / \mathrm{G} \\
{ }^{\mathrm{m}} \mathrm{G} / \mathrm{A},{ }^{\star} \mathrm{A} /{ }^{\star} \mathrm{A}\end{array}$ & $\begin{array}{l}251(78.7) \\
68(21.3)\end{array}$ & $\begin{array}{l}386(85.0) \\
68(15.0)\end{array}$ & $\begin{array}{c}\text { Referent } \\
1.7(1.1-2.6)\end{array}$ & $\begin{array}{c}\text { Referent } \\
2.00(1.2-3.4)\end{array}$ & $\begin{array}{c}118(68.2) \\
55(11.2)\end{array}$ & $\begin{array}{l}31(81.6) \\
07(1.4)\end{array}$ & $\begin{array}{c}\text { Referent } \\
9.7(4.3-21.8)\end{array}$ & $\begin{array}{c}\text { Referent } \\
9.7(3.6-25.9)\end{array}$ \\
\hline \multicolumn{9}{|l|}{ CYP2E1 } \\
\hline $\begin{array}{l}{ }^{n} \mathrm{c} 1 / \mathrm{c} 2, \mathrm{c} 2 / \mathrm{c} 2 \\
{ }^{\circ} \mathrm{c} 1 / \mathrm{c} 1\end{array}$ & $\begin{array}{c}78(24.4) \\
241(75.6)\end{array}$ & $\begin{array}{c}84(18.5) \\
370(81.5)\end{array}$ & $\begin{array}{c}\text { Referent } \\
1.3(0.9-1.9)\end{array}$ & $\begin{array}{c}\text { Referent } \\
1.5(0.7-3.5)\end{array}$ & $\begin{array}{c}41(23.7) \\
132(26.8)\end{array}$ & $\begin{array}{l}06(15.8) \\
32(6.5)\end{array}$ & $\begin{array}{c}\text { Referent } \\
3.0(0.3-28.8)\end{array}$ & $\begin{array}{c}\text { Referent } \\
9.7(2.5-37.5)-\end{array}$ \\
\hline \multicolumn{9}{|l|}{ GSTM1 } \\
\hline $\begin{array}{l}{ }^{\text {PGSTM1 }}{ }^{+} \\
{ }^{\mathrm{q}} \text { GSTM1 }\end{array}$ & $\begin{array}{l}203(65.3) \\
108(34.7)\end{array}$ & $\begin{array}{l}300(65.5) \\
158(34.5)\end{array}$ & $\begin{array}{c}\text { Referent } \\
1.1(0.7-1.5)\end{array}$ & $\begin{array}{c}\text { Referent } \\
1.0(0.5-1.9)\end{array}$ & $\begin{array}{c}125(69.1) \\
56(30.9)\end{array}$ & $\begin{array}{l}28(82.3) \\
06(17.7)\end{array}$ & $\begin{array}{c}\text { Referent } \\
2.0(0.2-22.1)\end{array}$ & $\begin{array}{c}\text { Referent } \\
-\end{array}$ \\
\hline \multicolumn{9}{|l|}{ GSTT1 } \\
\hline $\begin{array}{l}{ }^{r} \text { GSTT1 }{ }^{+} \\
{ }^{\mathrm{s}} \text { GSTT1 }\end{array}$ & $\begin{array}{l}198(63.7) \\
113(36.3)\end{array}$ & $\begin{array}{l}342(74.7) \\
116(25.3)\end{array}$ & $\begin{array}{c}\text { Referent } \\
1.5(1.0-2.1)\end{array}$ & $\begin{array}{c}\text { Referent } \\
-\end{array}$ & $\begin{array}{l}108(59.7) \\
73(40.3)\end{array}$ & $\begin{array}{l}25(73.5) \\
09(26.5)\end{array}$ & $\begin{array}{c}\text { Referent } \\
3.0(0.3-28.8)\end{array}$ & $\begin{array}{c}\text { Referent } \\
-\end{array}$ \\
\hline \multicolumn{9}{|l|}{ ALDH2 } \\
\hline $\begin{array}{l}{ }^{\mathrm{t}} 2 * 1 / 2 * 1 \\
{ }^{\mathrm{u}} 2 * 2 / 2 * 2,2 * 2 / 2 * 2\end{array}$ & $\begin{array}{c}211(97.2) \\
03(2.4)\end{array}$ & $\begin{array}{c}327(98.2) \\
00(0.0)\end{array}$ & $\begin{array}{c}\text { Referent } \\
0.0(0.0-0.0)\end{array}$ & $\begin{array}{c}\text { Referent } \\
-\end{array}$ & $\begin{array}{c}120(97.6) \\
06(2.8)\end{array}$ & $\begin{array}{c}21(100.0 \\
06(1.8)\end{array}$ & $\begin{array}{c}\text { Referent } \\
2.00(0.5-8.0)\end{array}$ & $\begin{array}{c}\text { Referent } \\
-\end{array}$ \\
\hline \multicolumn{9}{|l|}{$\mathrm{ADH} 2$} \\
\hline $\begin{array}{l}{ }^{\vee} 2 * 1 / 2 * 1 \\
{ }^{w} 2 * 2 / 2 * 2,2 * 2 / 2 * 2\end{array}$ & $\begin{array}{c}79(36.4) \\
138(63.6)\end{array}$ & $\begin{array}{l}124(37.1) \\
210(62.9)\end{array}$ & $\begin{array}{c}\text { Referent } \\
1.2(0.7-1.8)\end{array}$ & $\begin{array}{c}\text { Referent } \\
2.5(0.8-7.8)\end{array}$ & $\begin{array}{l}51(41.5) \\
72(58.5)\end{array}$ & $\begin{array}{l}06(28.6) \\
15(71.4)\end{array}$ & $\begin{array}{c}\text { Referent } \\
1.00(0.1-7.1)\end{array}$ & $\begin{array}{c}\text { Referent } \\
-\end{array}$ \\
\hline \multicolumn{9}{|c|}{ 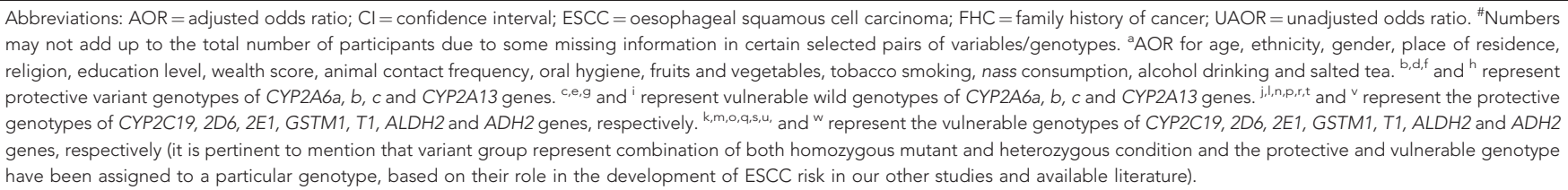 } \\
\hline
\end{tabular}

evidence on HPV association with ESCC is lacking (Kamangar et al, 2006). Like other studies (Tran et al, 2005; Akbari et al, 2006; Gao et al, 2009; Wu et al, 2011b), we found the higher risk when siblings than parents were affected by a cancer or when more than one relative were affected, however, we could not find this association in children-affected participants. This indicates that the siblings most likely share the same environmental exposures as children do with their parents.

Additive or multiplicative association of FHC with known risk factors of ESCC in Kashmir including hookah smoking, daily and close animal contact, alkaline salted tea intake, low socioeconomic status, living in adobe houses and use of biomass fuels shows shared environmental factors besides genetic predisposition can also elevate ESCC risk in a family.

Statistically insignificant interaction among the various risk factors and genetic markers with FHC indicates both the genetic factors and environmental risk factors act independently. However, the interaction with the adobe house shows that certain exposures in dwellers of such houses and the genetic alleles harboured by them work in a biologically synergistic way to influence the risk of ESCC. Participants living in poorly ventilated adobe houses possibly get high exposure to cooking fumes as well as household smoke from tobacco or biomass cooking fuel use. Use of animal dung and cooking fumes from adobe houses have been closely associated with the development of ESCC from other studies also (Wornat et al, 2001; Deziel et al, 2013).

Family history data were based on self-reported information from cases and controls rather than medically verified cancers in family members, which may be a source of bias (Glanz et al, 1999), and is a limitation of our study, irrespective of the fact that we had cross interviewed the attendants of the participants wherever possible about the history, site and type of malignancy among the relatives in a family. There are several strengths of this study. This is the first large hospital-based strictly matched case-control study from high-risk area of ESCC-Kashmir, addressing the modifying effect of FHC on ESCC risk in detail and exploring the interaction between FHC, lifestyle risk factors and certain genetic markers and adjustments of the results for multiple potential confounding 
factors. There is representation of participants from all the regions of the Kashmir. Also, there are least chances of subjective extrapolation and recall bias because of limited number of interviewers who got information in local language (Dar et al, 2012; Bhat et al, 2014). Finally, the similar hospital setting of the interview for both cases and controls should have improved the quality of collected information.

\section{CONCLUSION}

The study shows FHC, as a proxy of genetic, and shared environmental risk factors could be responsible for the high risk of ESCC in Kashmir.

\section{ACKNOWLEDGEMENTS}

We are highly indebted to all the subjects who willingly participated in this study. This study was financially supported by Extramural grant of Indian Council of Medical Research (ICMR), New Delhi, under IRIS ID 5/13/37/2007/-NCD-III.

\section{CONFLICT OF INTEREST}

The authors declare no conflict of interest.

\section{REFERENCES}

Abnet CC, Freedman ND, Hu N, Wang Z, Yu K, Shu XO, Yuan JM, Zheng W Dawsey SM, Dong LM, Lee MP, Ding T, Qiao YL, Gao YT, Koh WP, Xiang YB, Tang ZZ, Fan JH, Wang C, Wheeler W, Gail MH, Yeager M, Yuenger J, Hutchinson A, Jacobs KB, Giffen CA, Burdett L,

Fraumeni Jr JF, Tucker MA, Chow WH, Goldstein AM, Chanock SJ, Taylor PR (2010) A shared susceptibility locus in PLCE1 at 10q23 for gastric adenocarcinoma and esophageal squamous cell carcinoma. Nat Genet 42(9): 764-767.

Akbari MR, Malekzadeh R, Nasrollahzadeh D, Amanian D, Sun P, Islami F, Sotoudeh M, Semnani S, Boffeta P, Dawsey SM, Ghadirian P, Narod SA (2006) Familial risks of esophageal cancer among the Turkmen population of the Caspian littoral of Iran. Int J Cancer 119(5): 1047-1051.

Ayub SG, Ayub T, Khan SN, Rasool S, Mahboob ul H, Wani KA, Kuchay S, Lone MM, Andrabi KI (2011) Epidemiological distribution and incidence of different cancers in Kashmir valley-2002-2006. Asian Pac J Cancer Prev 12(7): $1867-1872$.

Bhat GA, Shah IA, Makhdoomi MA, Iqbal B, Rafiq R, Nabi S, Masood A, Lone MM, Dar NA (2014) CYP1A1 and CYP2E1 genotypes and risk of esophageal squamous cell carcinoma in a high-incidence region, Kashmir. Tumour Biol 35(6): 5323-5330.

Chang-Claude J, Becher H, Blettner M, Qiu S, Yang G, Wahrendorf J (1997) Familial aggregation of oesophageal cancer in a high incidence area in China. Int J Epidemiol 26(6): 1159-1165.

Dar NA, Bhat GA, Shah IA, Iqbal B, Makhdoomi MA, Nisar I, Rafiq R, Iqbal ST, Bhat AB, Nabi S, Shah SA, Shafi R, Masood A, Lone MM, Zargar SA, Najar MS, Islami F, Boffetta P (2012) Hookah smoking, nass chewing, and oesophageal squamous cell carcinoma in Kashmir, India. $\mathrm{Br}$ J Cancer 107(9): 1618-1623.

Dar NA, Bhat GA, Shah IA, Iqbal B, Rafiq R, Nabi S, Lone MM, Islami F, Boffetta P (2014a) Salt tea consumption and esophageal cancer: A possible role of alkaline beverages in esophageal carcinogenesis. Int J Cancer 136(6): E704-E710.

Dar NA, Bhat GA, Shah IA, Iqbal B, Rafiq R, Nabi S, Lone MM, Islami F, Boffetta P (2015) Salt tea consumption and esophageal cancer: a possible role of alkaline beverages in esophageal carcinogenesis. Int $J$ Cancer 136(6): E704-E710.

Dar NA, Islami F, Bhat GA, Shah IA, Makhdoomi MA, Iqbal B, Rafiq R, Lone MM, Abnet CC, Boffetta P (2013a) Poor oral hygiene and risk of esophageal squamous cell carcinoma in Kashmir. Br J Cancer 109(5): 1367-1372.

Dar NA, Islami F, Bhat GA, Shah IA, Makhdoomi MA, Iqbal B, Rafiq R, Lone MM, Boffetta P (2014b) Contact with animals and risk of oesophageal squamous cell carcinoma: outcome of a case-control study from Kashmir, a high-risk region. Occup Environ Med 71(3): 208-214.

Dar NA, Shah IA, Bhat GA, Makhdoomi MA, Iqbal B, Rafiq R, Nisar I, Bhat AB, Nabi S, Masood A, Shah SA, Lone MM, Zargar SA, Islami F, Boffetta P (2013b) Socioeconomic status and esophageal squamous cell carcinoma risk in Kashmir, India. Cancer Sci 104(9): 1231-1236.

De Stefani E, Deneo-Pellegrini H, Ronco AL, Boffetta P, Brennan P, Munoz N, Castellsague X, Correa P, Mendilaharsu M (2003) Food groups and risk of squamous cell carcinoma of the oesophagus: a case-control study in Uruguay. Br J Cancer 89(7): 1209-1214.

Desoubeaux N, Le Prieur A, Launoy G, Maurel J, Lefevre H, Guillois JM, Gignoux M (1999) Recent time trends in cancer of the oesophagus and gastric cardia in the region of Calvados in France, 1978-1995: a population based study. Eur J Cancer Prev 8(6): 479-486.

Deziel NC, Wei WQ, Abnet CC, Qiao YL, Sunderland D, Ren JS, Schantz MM, Zhang Y, Strickland PT, Abubaker S, Dawsey SM, Friesen MC, Roth MJ (2013) A multi-day environmental study of polycyclic aromatic hydrocarbon exposure in a high-risk region for esophageal cancer in China. J Expo Sci Environ Epidemiol 23(1): 52-59.

Dhillon PK, Farrow DC, Vaughan TL, Chow WH, Risch HA, Gammon MD, Mayne ST, Stanford JL, Schoenberg JB, Ahsan H, Dubrow R, West AB, Rotterdam H, Blot WJ, Fraumeni Jr JF (2001) Family history of cancer and risk of esophageal and gastric cancers in the United States. Int $J$ Cancer 93(1): 148-152.

Fareed M, Afzal M (2014) Estimating the inbreeding depression on cognitive behavior: a population based study of child cohort. PLoS One 9(10): e109585.

Franceschi S, Gloghini A, Maestro R, Barzan L, Bidoli E, Talamini R, Vukosavljevic T, Carbone A, Boiocchi M (1995) Analysis of the p53 gene in relation to tobacco and alcohol in cancers of the upper aero-digestive tract. Int J Cancer 60(6): 872-876.

Gaikovitch EA, Cascorbi I, Mrozikiewicz PM, Brockmoller J, Frotschl R, Kopke K, Gerloff T, Chernov JN, Roots I (2003) Polymorphisms of drugmetabolizing enzymes CYP2C9, CYP2C19, CYP2D6, CYP1A1, NAT2 and of P-glycoprotein in a Russian population. Eur J Clin Pharmacol 59(4): 303-312.

Gao Y, Hu N, Han X, Giffen C, Ding T, Goldstein A, Taylor P (2009) Family history of cancer and risk for esophageal and gastric cancer in Shanxi, China. BMC Cancer 9: 269.

Garavello W, Negri E, Talamini R, Levi F, Zambon P, Dal Maso L, Bosetti C, Franceschi S, La Vecchia C (2005) Family history of cancer, its combination with smoking and drinking, and risk of squamous cell carcinoma of the esophagus. Cancer Epidemiol Biomarkers Prev 14(6): 1390-1393.

Gholipour C, Shalchi RA, Abbasi M (2008) A histopathological study of esophageal cancer on the western side of the Caspian littoral from 1994 to 2003. Dis Esophagus 21(4): 322-327.

Glanz K, Grove J, Le Marchand L, Gotay C (1999) Underreporting of family history of colon cancer: correlates and implications. Cancer Epidemiol Biomarkers Prev 8: 635-639.

Guengerich FP (2008) Cytochrome p450 and chemical toxicology. Chem Res Toxicol 21(1): 70-83.

Hemminki K, Li X (2002) Cancer risks in second-generation immigrants to Sweden. Int J Cancer 99(2): 229-237.

Hemminki K, Li X, Czene K (2002) Cancer risks in first-generation immigrants to Sweden. Int J Cancer 99(2): 218-228.

Hemminki K, Vaittinen P, Dong C, Easton D (2001) Sibling risks in cancer: clues to recessive or X-linked genes? Br J Cancer 84(3): 388-391.

Hiyama T, Yoshihara M, Tanaka S, Chayama K (2007) Genetic polymorphisms and esophageal cancer risk. Int J Cancer 121(8): 1643-1658.

Islami F, Kamangar F, Nasrollahzadeh D, Aghcheli K, Sotoudeh M, AbediArdekani B, Merat S, Nasseri-Moghaddam S, Semnani S, Sepehr A, Wakefield J, Moller H, Abnet CC, Dawsey SM, Boffetta P, Malekzadeh R (2009) Socio-economic status and oesophageal cancer: results from a population-based case-control study in a high-risk area. Int J Epidemiol 38(4): 978-988.

Islami F, Kamangar F, Nasrol- lahzadeh D, Moller H, Boffetta P, Malekzadeh R (2009) Oesophageal cancer in Golestan Province, a highincidence area in northernIran-A review. Eur J Cancer 45: 3156-3165. 
Jemal A, Bray F, Center MM, Ferlay J, Ward E, Forman D (2011) Global cancer statistics. CA Cancer J Clin 61(2): 69-90.

Jia N, Wen X, Zhang N, Yang Y, Zhang L, Wang X, Wang N, Wen D (2014) Younger age of onset and multiple primary lesions associated with esophageal squamous cell carcinoma cases with a positive family history of the cancer suggests genetic predisposition. Chin Med J 127(15): 2779-2783.

Kamangar F, Qiao YL, Schiller JT, Dawsey SM, Fears T, Sun XD, Abnet CC, Zhao P, Taylor PR, Mark SD (2006) Human papillomavirus serology and the risk of esophageal and gastric cancers: results from a cohort in a highrisk region in China. Int J Cancer 119(3): 579-584.

Kato I, Tominaga S, Suzuki T (1990) Correspondence in cancer history between husbands and wives. Jpn J Cancer Res 81(6-7): 584-589.

Khuroo MS, Zargar SA, Mahajan R, Banday MA (1992) High incidence of oesophageal and gastric cancer in Kashmir in a population with special personal and dietary habits. Gut 33(1): 11-15.

Ko JM, Zhang P, Law S, Fan Y, Song YQ, Zhao XK, Wong EH, Tang S, Song X, Lung ML, Wang LD (2014) Identity-by-descent approaches identify regions of importance for genetic susceptibility to hereditary esophageal squamous cell carcinoma. Oncol Rep 32(2): 860-870.

Lagergren J, Ye W, Lindgren A, Nyren O (2000) Heredity and risk of cancer of the esophagus and gastric cardia. Cancer Epidemiol Biomarkers Prev 9(7): 757-760.

LeMarchand L, Wilkinson GR, Wilkens LR (1999) Genetic and dietary predictors of CYP2E1 activity: a phenotyping study in Hawaii Japanese using chlorzoxazone. Cancer Epidemiol Biomarkers Prev 8: 495-500.

Levine MS, Rubesin SE (2005) Diseases of the esophagus: diagnosis with esophagography1. Radiology 237(2): 414-427.

Lichtenstein P, Holm NV, Verkasalo PK, Iliadou A, Kaprio J, Koskenvuo M, Pukkala E, Skytthe A, Hemminki K (2000) Environmental and heritable factors in the causation of cancer-analyses of cohorts of twins from Sweden, Denmark, and Finland. N Engl J Med 343(2): 78-85.

Louwman WJ, Aarts MJ, Houterman S, van Lenthe FJ, Coebergh JW, JanssenHeijnen ML (2010) A 50\% higher prevalence of life-shortening chronic conditions among cancer patients with low socioeconomic status. $\mathrm{Br} \mathrm{J}$ Cancer 103(11): 1742-1748.

Lukanich JM (2003) Section I: epidemiological review. Semin Thorac Cardiovasc Surg 15(2): 158-166.

Makhdoomi MA, Shah IA, Bhat GA, Amin S, Lone MM, Islami F, Dar NA (2015) Association between GSTM1 and GSTT1 polymorphisms and esophageal squamous cell carcinoma: results from a case-control study in Kashmir, India. Tumour Biol 36(4): 2613-2619.

Malik MA, Umar M, Gupta U, Zargar SA, Mittal B (2014) Phospholipase C epsilon 1 (PLCE1 rs2274223A > G, rs3765524C > T and rs7922612C > T) polymorphisms and esophageal cancer risk in the Kashmir Valley. Asian Pac J Cancer Prev 15(10): 4319-4323.

Malik MA, Zargar SA, Mittal B (2011) A six-nucleotide deletion polymorphism in the casp8 promoter is associated with reduced risk of esophageal and gastric cancers in Kashmir valley. Indian J Hum Genet 17(3): 152-156.

Pink RC, Bailey TA, Iputo JE, Sammon AM, Woodman AC, Carter DR (2011) Molecular basis for maize as a risk factor for esophageal cancer in a South African population via a prostaglandin E2 positive feedback mechanism. Nutr Cancer 63(5): 714-721.

Rasool MT, Lone MM, Wani ML, Afroz F, Zaffar S, Mohib-ul Haq M (2012) Cancer in Kashmir, India: burden and pattern of disease. J Cancer Res Ther 8(2): 243-246.

Shao YN, Shen J, Tan YF (1997) [A study on the etiology and epidemiology of familial aggregation in arteriosclerotic cerebral infarction]. Zhonghua liu xing bing xue za zhi=Zhonghua liuxingbingxue zazhi 18(5): 275-278.

Shi Y, Luo GJ, Zhang L, Shi J, Zhang DQ, Chen JM, Chen XB, Li ZD, Zhao Q (2012) Interaction between alcohol consumption and CYP 2C19 gene polymorphism in relation to oesophageal squamous cell carcinoma. PLoS One 7(9): e43412.

Siddiqi M, Tricker AR, Preussmann R (1988) The occurrence of preformed $\mathrm{N}$-nitroso compounds in food samples from a high risk area of esophageal cancer in Kashmir, India. Cancer Lett 39(1): 37-43.

Tan W, Wu J, Tang H, Lin D (2001) Expression of cytochrome P4502E1 in human liver: relationship between genotype and phenotype in Chinese. Sci China C Life Sci 44: 356-364.

Thrift AP, Nagle CM, Fahey PP, Russell A, Smithers BM, Watson DI, Whiteman DC (2012) The influence of prediagnostic demographic and lifestyle factors on esophageal squamous cell carcinoma survival. Int $J$ Cancer 131(5): E759-E768.

Tran GD, Sun XD, Abnet CC, Fan JH, Dawsey SM, Dong ZW, Mark SD, Qiao YL, Taylor PR (2005) Prospective study of risk factors for esophageal and gastric cancers in the Linxian general population trial cohort in China. Int J Cancer 113(3): 456-463.

Turati F, Edefonti V, Bosetti C, Ferraroni M, Malvezzi M, Franceschi S, Talamini R, Montella M, Levi F, Dal Maso L, Serraino D, Polesel J, Negri E, Decarli A, La Vecchia C (2013) Family history of cancer and the risk of cancer: a network of case-control studies. Ann Oncol 24(10): 2651-2656.

Wang AH, Liu Y, Wang B, He YX, Fang YX, Yan YP (2014) Epidemiological studies of esophageal cancer in the era of genome-wide association studies. World J Gastrointest Pathophysiol 5(3): 335-343.

Wang AH, Sun CS, Li LS, Huang JY, Chen QS, Xu DZ (2004) Genetic susceptibility and environmental factors of esophageal cancer in Xi'an. World J Gastroenterol 10(7): 940-944.

Wang LD, Zhou FY, Li XM, Sun LD, Song X, Jin Y, Li JM, Kong GQ, Qi H, Cui J, Zhang LQ, Yang JZ, Li JL, Li XC, Ren JL, Liu ZC, Gao WJ, Yuan L, Wei W, Zhang YR, Wang WP, Sheyhidin I, Li F, Chen BP, Ren SW, Liu B, Li D, Ku JW, Fan ZM, Zhou SL, Guo ZG, Zhao XK, Liu N, Ai YH, Shen FF, Cui WY, Song S, Guo T, Huang J, Yuan C, Wu Y, Yue WB, Feng CW, Li HL, Wang Y, Tian JY, Lu Y, Yuan Y, Zhu WL, Liu M, Fu WJ, Yang X, Wang HJ, Han SL, Chen J, Han M, Wang HY, Zhang P, Dong JC, Xing GL, Wang R, Guo M, Chang ZW, Liu HL, Guo L, Yuan ZQ, Liu H, Lu Q, Yang LQ, Zhu FG, Yang XF, Feng XS, Wang Z, Li Y, Gao SG, Qige Q, Bai LT, Yang WJ, Lei GY, Shen ZY, Chen LQ, Li EM, Xu LY, Wu ZY, Cao WK, Wang JP, Bao ZQ, Chen JL, Ding GC, Zhuang X, Zhou YF, Zheng HF, Zhang Z, Zuo XB, Dong ZM, Fan DM, He X, Wang J, Zhou Q, Zhang QX, Jiao XY, Lian SY, Ji AF, Lu XM, Wang JS, Chang FB, Lu CD, Chen ZG, Miao JJ, Fan ZL, Lin RB, Liu TJ, Wei JC, Kong QP, Lan Y, Fan YJ, Gao FS, Wang TY, Xie D, Chen SQ, Yang WC, Hong JY, Wang L, Qiu SL, Cai ZM, Zhang XJ (2010) Genome-wide association study of esophageal squamous cell carcinoma in Chinese subjects identifies susceptibility loci at PLCE1 and C20orf54. Nat Genet 42(9): 759-763.

Wen D, Wang S, Zhang L, Zhang J, Wei L, Zhao X (2006) Differences of onset age and survival rates in esophageal squamous cell carcinoma cases with and without family history of upper gastrointestinal cancer from a highincidence area in North China. Fam Cancer 5(4): 343-352.

Wornat MJ, Ledesma EB, Sandrowitz AK, Roth MJ, Dawsey SM, Qiao YL, Chen W (2001) Polycyclic aromatic hydrocarbons identified in soot extracts from domestic coal-burning stoves of Henan Province, China. Environ Sci Technol 35(10): 1943-1952.

Wu C, Hu Z, He Z, Jia W, Wang F, Zhou Y, Liu Z, Zhan Q, Liu Y, Yu D, Zhai K, Chang J, Qiao Y, Jin G, Shen Y, Guo C, Fu J, Miao X, Tan W, Shen H, Ke Y, Zeng Y, Wu T, Lin D (2011a) Genome-wide association study identifies three new susceptibility loci for esophageal squamous-cell carcinoma in Chinese populations. Nat Genet 43(7): 679-684.

Wu C, Kraft P, Zhai K, Chang J, Wang Z, Li Y, Hu Z, He Z, Jia W, Abnet CC, Liang L, Hu N, Miao X, Zhou Y, Liu Z, Zhan Q, Liu Y, Qiao Y, Jin G, Guo C, Lu C, Yang H, Fu J, Yu D, Freedman ND, Ding T, Tan W, Goldstein AM, Wu T, Shen H, Ke Y, Zeng Y, Chanock SJ, Taylor PR, Lin D (2012) Genome-wide association analyses of esophageal squamous cell carcinoma in Chinese identify multiple susceptibility loci and geneenvironment interactions. Nat Genet 44(10): 1090-1097.

Wu C, Wang Z, Song X, Feng XS, Abnet CC, He J, Hu N, Zuo XB, Tan W, Zhan Q, Hu Z, He Z, Jia W, Zhou Y, Yu K, Shu XO, Yuan JM, Zheng W, Zhao XK, Gao SG, Yuan ZQ, Zhou FY, Fan ZM, Cui JL, Lin HL, Han XN, Li B, Chen X, Dawsey SM, Liao L, Lee MP, Ding T, Qiao YL, Liu Z, Liu Y, Yu D, Chang J, Wei L, Gao YT, Koh WP, Xiang YB, Tang ZZ, Fan JH, Han JJ, Zhou SL, Zhang P, Zhang DY, Yuan Y, Huang Y, Liu C, Zhai K, Qiao Y, Jin G, Guo C, Fu J, Miao X, Lu C, Yang H, Wang C, Wheeler WA, Gail M, Yeager M, Yuenger J, Guo ET, Li AL, Zhang W, Li XM, Sun LD, Ma BG, Li Y, Tang S, Peng XQ, Liu J, Hutchinson A, Jacobs K, Giffen C, Burdette L, Fraumeni Jr JF, Shen H, Ke Y, Zeng Y, Wu T, Kraft P, Chung CC, Tucker MA, Hou ZC, Liu YL, Hu YL, Wang L, Yuan G, Chen LS, Liu X, Ma T, Meng H, Sun L, Ku JW, Zhou YF, Yang LQ, Qige Q, Yang WJ, Lei GY, Chen LQ, Li EM, Yuan L, Yue WB, Wang R, Wang LW, Fan XP, Zhu FH, Zhao WX, Mao YM, Zhang M, Xing GL, Li JL, Han M, Ren JL, Liu B, Ren SW, Kong QP, Li F, Sheyhidin I, Wei W, Zhang YR, Feng CW, Wang J, Yang YH, Hao HZ, Bao QD, Liu BC, Wu AQ, Xie D, Yang WC, Zhao XH, Chen SQ, Hong JY, Zhang XJ, Freedman ND, Goldstein AM, Lin D, Taylor PR, Wang LD, Chanock SJ (2014) Joint analysis of three 
genome-wide association studies of esophageal squamous cell carcinoma in Chinese populations. Nat Genet 46(9): 1001-1006.

Wu M, Zhang ZF, Kampman E, Zhou JY, Han RQ, Yang J, Zhang XF, Gu XP, Liu AM, van't Veer P, Kok FJ, Zhao JK (2011b) Does family history of cancer modify the effects of lifestyle risk factors on esophageal cancer? A population-based case-control study in China. Int J Cancer 128(9): 2147-2157.

Xing D, Tan W, Lin D (2003) Genetic polymorphisms and susceptibility to esophageal cancer among Chinese population (review). Oncol Rep 10(5): $1615-1623$.

Yadav SS, Ruwali M, Pant MC, Shukla P, Singh RL, Parmar D (2010) Interaction of drug metabolizing cytochrome P450 2D6 poor metabolizers with cytochrome P450 2C9 and 2C19 genotypes modify the susceptibility to head and neck cancer and treatment response. Mutat Res 684: 49-55.

Yang CS YJ, Ishizaki H, Hong J (1990) Cytochrome P450IIE1: roles in nitrosamine metabolism and mechanisms of regulation. Drug Metab Rev 22: $147-159$.

Yang CX, Matsuo K, Ito H, Hirose K, Wakai K, Saito T, Shinoda M, Hatooka S, Mizutani K, Tajima K (2005a) Esophageal cancer risk by ALDH2 and $\mathrm{ADH} 2$ polymorphisms and alcohol consumption: exploration of gene- environment and gene-gene interactions. Asian Pac J Cancer Prev 6(3): $256-262$.

Yang CX, Matsuo K, Wang ZM, Tajima K (2005b) Phase I/II enzyme gene polymorphisms and esophageal cancer risk: a meta-analysis of the literature. World J Gastroenterol 11(17): 2531-2538.

Zhang W, Bailey-Wilson JE, Li W, Wang X, Zhang C, Mao X, Liu Z, Zhou C, Wu M (2000) Segregation analysis of esophageal cancer in a moderately high-incidence area of northern China. Am J Hum Genet 67(1): 110-119.

Zhong S, Zhao W, Lu C, Li B, Yuan Y, Guo D, Chang Z, Jiao B, Yang L (2013) Glutathione S-transferase M1 null genotype contributes to increased risk of esophageal carcinoma in Chinese population. Tumour Biol 34(4): 2403-2407.

This work is published under the standard license to publish agreement. After 12 months the work will become freely available and the license terms will switch to a Creative Commons AttributionNonCommercial-Share Alike 4.0 Unported License

Supplementary Information accompanies this paper on British Journal of Cancer website (http://www.nature.com/bjc) 